Rev. Latino-Am. Enfermagem

2017;25:e2943

DOI: $10.1590 / 1518-8345.2080 .2943$

www.eerp.usp.br/rlae

\title{
Self-care competence in the administration of insulin in older people aged 70 or over $^{1}$
}

\author{
Mayara Sousa Vianna² \\ Patrícia Aparecida Barbosa Silva ${ }^{3}$ \\ Cíntia Vieira do Nascimento ${ }^{4}$ \\ Sônia Maria Soares ${ }^{5}$
}

Objective: to analyze the self-care competence in the administration of insulin performed by older people aged 70 or over. Method: cross-sectional study carried out with 148 older people aged 70 or over, who performed self-administration of insulin. Data collection was carried out using a structured questionnaire and an adapted guide for the application of the Scale to Identify Self-Care Competence of Patients with Diabetes, at the participants' home. Data analysis included descriptive and inferential statistical tests, with forward logistic regression. Results: the prevalence of self-care competence in the administration of insulin was $35.1 \%$. Handwashing error was the most frequent in self-administration of insulin. Self-care competence was negatively associated with retirees and positively associated with senior patients who performed capillary blood glucose monitoring and skin pinching during insulin application. Conclusion: there was low self-care competence and it was associated with both the sociodemographic and the clinical characteristics with regard to self-application of insulin by the older people.

Descriptors: Insulin; Elderly; Self-administration; Diabetes Mellitus; Nursing.

\footnotetext{
Paper extracted from Master's Thesis "Competence for self-care insulin administration by septuagenarian or more older", presented to Escola de Enfermagem, Universidade Federal de Minas Gerais, Belo Horizonte, MG, Brazil.

2 MSc, RN, Departamento de Atenção à Saúde do Trabalhador, Universidade Federal de Minas Gerais, Belo Horizonte, MG, Brazil.

$3 \mathrm{PhD}$.

${ }^{4}$ Doctoral student, Escola de Enfermagem, Universidade Federal de Minas Gerais, Belo Horizonte, MG, Brazil. RN, Hospital Júlia Kubitschek, Fundação Hospitalar do Estado de Minas Gerais, Belo Horizonte, MG, Brazil.

${ }_{5}^{5} \mathrm{PhD}$, Associate Professor, Escola de Enfermagem, Universidade Federal de Minas Gerais, Belo Horizonte, MG, Brazil.
}

\section{How to cite this article}

Vianna MS, Silva PAB, Nascimento CV, Soares SM. Self-care competence in the administration of insulin in older people aged 70 or over. Rev. Latino-Am. Enfermagem. 2017;25:e2943. [Access † _ _ ]; Available in: DOI: http://dx.doi.org/10.1590/1518-8345.2080.2943. day month year 


\section{Introduction}

Population aging and the influence of risk factors, such as obesity, sedentary lifestyle and inadequate food consumption, have contributed to the increase in the prevalence of chronic non-communicable diseases, especially Diabetes Mellitus (DM)(1). In 2015, there were an estimated 415 million (8.8\%) diabetic people worldwide, and people with this disease are expected to increase to 642 million in the next two decades $^{(2)}$. In line with the global trend, the prevalence of DM in the Brazilian scenario increased from 3.6\% (95\%CI: $3.3-3.8)$ in the 1990 s to $6.1 \%$ (95\%CI: 5.6-6.7) in $2015^{(1)}$, increasing with aging $(19.8 \%$ in individuals aged 65 years or over) ${ }^{(3)}$. This chronic condition was responsible for 62,466 deaths in the country and 1,015 wasted years, disability-adjusted life-years per 100,000 inhabitants $^{(1)}$.

In the literature, it is observed that the geriatric population is more susceptible to micro and macrovascular complications due to a decrease in physiological reserve capacity, which leads to functional decline ${ }^{(4)}$. In addition, older adults aged 75 years or over are at an increased risk for death due to hyperglycemic events, as well as hospital readmissions due to hypoglycemic episodes, compared to younger age groups $^{(5)}$.

Among the therapeutic alternatives for metabolic control, there is the insulin therapy. Recent data from a series of studies of the National Health and Nutrition Examination Surveys (NHANES) program, which included 4,947 diabetic participants ( $\geq 20$ years) in the United States of America, showed a prevalence of insulin therapy of $29.1 \%$ (95\%CI: $26.7-31.5)$ in the period from 2005 to 2012. Considering only older people ( $\geq 65$ years), this percentage was similar to that found for adults (27.8-29.8\%, p-value $=0.391)$, and $15.7 \%$ also used oral antidiabetic agents ${ }^{(6)}$.

According to current guidelines in the country, insulin therapy is indicated for people with type 2 DM (DM2), when changes in lifestyle and use of metformin are not sufficient for glycemic control after one month of therapy. Insulin therapy is also indicated when glycosylated hemoglobin (HbA1c) values are above $8.5 \%$, even after the use of the maximum dose of metformin and persistent symptoms of hyperglycemia, or when serum glucose levels are $>300$ milligrams per deciliter $(\mathrm{mg} / \mathrm{dL})^{(7)}$.

Self-administration of insulin requires from the user the mastery of the cognitive and psychomotor skills that constitute the learning of different procedures, including storage, transportation, preparation of the solution and application, as well as handling of syringes, needles or injection pens ${ }^{(7)}$. Therefore, proper use of insulin at home requires training, changes in daily life, discipline, availability for learning and dedication and interest to perform self-care. The types of insulin and its forms of use are varied and, depending on the number of daily applications and the effect of the dose and type of insulin used, the responsibility of the patient in the control of this chronic condition increases ${ }^{(8)}$.

The self-administration of insulin requires the individual to have competence for such activity. Competence is the ability or capacity of an individual to perform certain activities, make decisions in the context of certain events, facts or circumstances. Self-care competence is the power of individuals to perform their own care in order to meet their particular needs. Such competence accompanies the development of individuals, beginning in childhood, reaching the highest degree of development in adulthood and decreasing in old age ${ }^{(9)}$.

Inaccuracies in the self-administration of insulin may adversely influence metabolic control, accelerate the progression of diabetes complications, and lead to discontinuation of treatment ${ }^{(10)}$. In addition, this situation is even more worrying among older people due to other factors added, such as visual deficit and cognitive and motor impairment, which make it difficult the self-administration of insulin and the Capillary Glycemia (CG) monitoring(11).

The epidemiological aspects of DM have been extensively studied(1,12), whereas there is a lack of information on self-administration of insulin, especially in older people. Previous studies at national level have identified frequent errors in the preparation and administration of insulin(10), as well as improper disposal of residues generated by the administration of insulin at home $^{(13)}$. This reality is not restricted only to Brazil, being also highlighted in studies at international level(14-16).

Therefore, in order to enhance the knowledge on the subject, the objective of this study was to analyze the self-care competence in the administration of insulin performed by older people aged 70 or over with DM.

\section{Method}

This cross-sectional study was carried out in the Northwest Sanitary District of the city of Belo Horizonte, MG, Brazil, with older people aged 70 or over, who performed self-administration of insulin. 
The older people who met the criteria mentioned above were considered as potential participants. Older people whose electronic medical records did not contain telephone contact information $(n=283)$, telephone contact without success $(n=213)$, change of address $(n=25)$, death $(n=46)$ and refusal to participate $(n=82)$ were excluded from the sample.

The study population consisted of individuals aged 70 years or over, enrolled in the Health System Management Network (Sisrede), who acquired insulin at the Health Centers $(\mathrm{HC})$ of the Northwest District, from January 2014 to June 2015, no matter if they had DM type 1 or DM type 2.

For the sample size calculation, it was considered population size $(N)$ equal to 1.193 , proportion $(P)$ of $27.54 \%{ }^{(17)}$ for the self-administration of insulin, $95 \%$ confidence interval (expressed as $Z^{2} \alpha / 2=1.96$ ) and a maximum tolerable error $(\varepsilon)$ of $0.05^{(18)}$. The total sample consisted of 245 individuals.

A team composed of one nurse and four nursing students carried out data collection, in three stages. In the first stage, the team responsible for data collection was instructed to systematize data collection, in addition to enhance the knowledge about DM, insulin use and research methodology. A pilot study with five individuals was also carried out in order to determine the appropriate adjustments in the collection instruments, the estimated collection duration and other schedules.

In the second stage, a search for the names of older people, identified according to the $\mathrm{HC}$, was performed in the Sisrede electronic medical record, in order to identify the Community Health Agents ( $\mathrm{CHA})$, the Family Health Teams, the telephone contact and the addresses of the older people. In this way, contact with the managers of the participating $\mathrm{HC}$ was made to explain the project. Subsequently, telephone contact was made with each of the older people or their caregivers to identify those who performed self-administration of insulin and to schedule a home visit. All older people who performed self-administration of insulin were selected in order to schedule a home visit, in up to three attempts.

In the third stage, two data collection instruments were used: the questionnaire and the adapted guide for the application of the Scale to Identify Self-Care Competence of Patients with Diabetes $(E C D A C)^{(19)}$. This scale was developed and validated by a nurse in 1982, at the Federal University of Santa Catarina (UFSC), based on the concept of self-care competence, according to the Dorothea Orem's theory ${ }^{(9)}$. In order to measure the reliability of the instrument, it was applied to 81 adults with DM, at their homes or at health institutions, and an alpha coefficient of 0.92 was obtained for the 27 items of the questionnaire ${ }^{(19)}$.

The first part of the questionnaire includes the sociodemographic and clinical data of the older people, as well as the register of alterations of the physical, mental and motivational capacities, which can affect self-care competence. The second part concerns the instrument to support the application of the MiniMental State Examination (MMSE). The third part of the instrument was used to register the errors found in the self-administration of insulin performed by the older people, with 20 previously defined errors as references, including the pre-application, application and postapplication phases. For this purpose, self-administration of insulin performed by the older people at home was monitored and the errors and successes found were registered. Subsequently, the older person was instructed on the correct practices for self-application of insulin. Those who presented errors that could lead to the application of incorrect doses of insulin were immediately instructed on the proper way, and their relatives were informed about the risks of the selfapplication of insulin performed by the older people.

In this study, self-care competence was the dependent variable (up to 77 points for unsatisfactory self-care competence and 78 points or more for satisfactory self-care competence). The independent variables were the sociodemographic variables (age group, place of birth, sex, marital status, retirement, occupation, education level and living arrangement), clinical variables (length of DM diagnosis, family history, sedentary lifestyle, smoking, length of insulin use, type of insulin, use of injection pens, use of syringe, needle reuse, CG monitoring performance, CG mapping, current values of fasting glycemia levels and HbA1c values registered in the electronic medical record, comorbidities, number of medications, MMSE results), variables related to limitations for self-care (physical, mental and motivational limitations) and variables related to the self-application of insulin performed by older people.

The collected data were inserted into the database built using the Statistical Package for the Social Sciences (SPSS), version 20.0, which facilitated the analysis of the results.

The sample size was equal to 148 , unlike the prior estimate of 245 , due to difficulties in terms of telephone 
contact and agreement to schedule the home visits by telephone, making it necessary to calculate the sample power. The significance level was set at $5 \%$ and the null hypothesized proportion was $27.54 \%$. Maximum likelihood estimation was considered for the alternative hypothesis, that is, the estimate for the proportion found in the sample was $45.8 \%$, resulting in a power of $0.99^{(20-21)}$.

The descriptive analysis for the variables was performed using frequency distribution tables. Continuous variables were expressed as mean \pm Standard Deviation (SD), for variables with parametric distribution, and as median with Interquartile Range (IQR Q3-Q1), for variables with non-parametric distribution. Categorical variables were expressed as proportions or percentages.

Continuous variables were tested for normal distribution using Kolmogorov-Smirnov test and Spearman's Rho correlation analysis was calculated between self-care competence scores and physical, mental and motivational limitations.

In the univariate analysis, categorical variables were compared using Pearson Chi-square test $\left(\chi^{2}\right)$ or Fisher's exact test. For statistical modeling, a critical value of $p \leq 0.20$ was used for entry into the multivariate model. A logistic regression model was developed using the forward method to evaluate the direction and magnitude of the associations of each independent variable in relation to the response variable (self-care competence). For this analysis, $\mathrm{p}<0.05$ was considered as statistically significant. The achieved values were expressed as Odds Ratio (OR) and their respective 95\% confidence intervals. The final model fit was assessed using goodness-of-fit test.

The Research Ethics Committee approved this study under Protocol number 1.004.545, in accordance with Resolution 466/2012 of the National Health Council(22).

\section{Results}

The profile of older people was characterized as a predominantly female population (64.2\%), coming from the interior of the state of Minas Gerais (61.5\%), without a spouse $(54.7 \%)$, with a level of education equal to or less than four years of study (59.5\%). The predominant age group was from 70 to 79 years $(73.6 \%)$. It was observed that $8.8 \%$ of the older people still worked in the period in which the study was carried out, whereas $78.4 \%$ were retired. Regarding the living arrangement, $14.2 \%$ of the study population lived alone.

The majority of older people reported having Systemic Arterial Hypertension (SAH) (93.9\%), dyslipidemia
(64.9\%) and diabetic retinopathy (31.8\%). It was found that $72.3 \%$ of older people used five to ten medications. In addition, $65.5 \%$ of individuals reported a sedentary lifestyle and $7.4 \%$ smoked.

Regarding DM, 76.8\% had the disease for more than ten years and $58.9 \%$ used insulin for less than 10 years. Family history of DM was observed in $63.5 \%$.

The use of syringes for the application of insulin was frequent among older people in $90.5 \%$ of the cases, and $70.3 \%$ reused the needle of the syringe or the needle of the injection pen from two to eight times. Only $67.6 \%$ of older people often perform CG monitoring, and only $37.2 \%$ had the capillary blood glycemia values registered in a graphic format. Regarding the results of the laboratory tests, fasting blood glycemia levels were higher than $130 \mathrm{mg} / \mathrm{dL}$ in $61.6 \%$ and $52.1 \%$ had $\mathrm{HbA} 1 \mathrm{c}$ levels equal to or greater than $8 \%$.

The evaluation of errors (non performed or improperly performed) in the self-application of insulin showed a higher prevalence of errors during handwashing (87.2\%), aspiration of air into the syringe and injection into the insulin vial (74.3\%) and during the disposal of sharp objects into a hard flask (73.1\%).

The following are the frequencies of procedures properly or improperly performed, as well as the nonperformance of the procedures by older people (Table 1 ).

The analysis of the associations between self-care competence scores and physical, mental and motivational limitations showed a strong correlation only with respect to mental limitation $(r=0.824)$, whereas motivational limitation showed a moderate correlation $(r=0.545)$ and physical limitation showed a weak correlation ( $r=0.353)$.

The results of univariate analysis demonstrated a significant association between an adequate self-care competence and several factors such as: not being retired, use of two types of insulin, needle reuse from two to eight times, performance of CG monitoring, preserved mental state, proper delimitation of the insulin site application, correct performance of skin pinching for application and needle insertion for application at a $90^{\circ}$ angle.

Regarding the multivariate model, there was a negative association between self-care competence and retirement, and a positive association between self-care competence and the performance of CG monitoring and the performance of skin pinching for insulin application, as shown in Table 2. 
Table 1 - Frequency of errors and successes in the self-administration of insulin. Northwest Sanitary District. Belo Horizonte, MG, Brazil, $2015(\mathrm{~N}=148)$

\begin{tabular}{|c|c|c|c|c|c|c|c|c|}
\hline \multirow{4}{*}{ Variables } & \multicolumn{8}{|c|}{ Performance of the procedure } \\
\hline & \multicolumn{6}{|c|}{ Yes } & \multicolumn{2}{|c|}{ No } \\
\hline & \multicolumn{2}{|c|}{ Properly } & \multicolumn{2}{|c|}{ Improperly } & \multicolumn{2}{|c|}{ Total } & \multirow{2}{*}{ n } & \multirow{2}{*}{$\%$} \\
\hline & $\mathbf{n}$ & $\%$ & $\mathbf{n}$ & $\%$ & $\mathbf{N}$ & $\%$ & & \\
\hline \multicolumn{9}{|l|}{ Pre-application } \\
\hline Handwashing & 19 & 90.5 & 2 & 9.5 & 21 & 14.2 & 127 & 85.8 \\
\hline Withdrawal of insulin from the refrigerator ${ }^{(n=141)}$ & 39 & 59.1 & 27 & 40.9 & 66 & 46.8 & 75 & 53.2 \\
\hline Organization of the material for use ${ }^{(n=147)}$ & 102 & 87.2 & 15 & 12.8 & 117 & 79.6 & 30 & 20.4 \\
\hline Differentiation of insulin types ${ }^{(n=42)}$ & 36 & 97.3 & 1 & 2.7 & 37 & 88.1 & 5 & 11.9 \\
\hline \multicolumn{9}{|l|}{ Application technique } \\
\hline Rotation of application sites & 76 & 82.6 & 16 & 17.4 & 92 & 62.2 & 56 & 37.8 \\
\hline Application site delimitation & 109 & 91.6 & 10 & 8.4 & 119 & 80.4 & 29 & 19.6 \\
\hline Disinfection of the insulin vial $\left.\right|^{(\mathrm{n}=140)}$ & 46 & 88.5 & 6 & 11.5 & 52 & 37.1 & 88 & 62.9 \\
\hline Shaking NPH insulin ${ }^{(n=141)}$ & 80 & 80.0 & 20 & 20.0 & 100 & 70.9 & 41 & 29.1 \\
\hline Aspiration of regular insulin before $\mathrm{NPH}^{(\mathrm{n}=28)}$ & 19 & 95.0 & 1 & 5.0 & 20 & 71.4 & 8 & 28.6 \\
\hline Aspiration of the prescribed dose of insulin ${ }^{(n=143)}$ & 120 & 100.0 & 0 & 0.0 & 120 & 83.9 & 23 & 16.1 \\
\hline Aspiration of air into the syringe and injection ${ }^{(n=140)}$ & 36 & 100.0 & 0 & 0.0 & 36 & 25.7 & 104 & 74.3 \\
\hline Removal of air bubbles $^{(n=125)}$ & 46 & 76.7 & 14 & 23.3 & 60 & 48.0 & 65 & 52.0 \\
\hline Skin pinching for application & 99 & 94.3 & 6 & 5.7 & 105 & 70.9 & 43 & 29.1 \\
\hline $90^{\circ}$ angulation for needle insertion & 105 & 100.0 & 0 & 0.0 & 105 & 70.9 & 43 & 29.1 \\
\hline Subcutaneous needle insertion & 127 & 93.4 & 9 & 6.6 & 136 & 91.9 & 12 & 8.1 \\
\hline Wait time to withdraw of needle & 44 & 89.8 & 5 & 10.2 & 49 & 33.1 & 99 & 66.9 \\
\hline \multicolumn{9}{|l|}{ Post-application } \\
\hline Care in reusing the needle $\mathrm{e}^{(\mathrm{n}=142)}$ & 106 & 85.5 & 18 & 14.5 & 124 & 87.3 & 18 & 12.7 \\
\hline Disposal of sharps into a hard flask ${ }^{(n=145)}$ & 39 & 50.0 & 39 & 50.0 & 78 & 53.8 & 67 & 46.2 \\
\hline Bleeding: pressure on the application site ${ }^{(n=127)}$ & 42 & 68.9 & 19 & 31.1 & 61 & 48.0 & 66 & 52.0 \\
\hline Storage of the opened insulin vial up to $30^{\circ} \mathrm{C}^{(\mathrm{n}=147)}$ & 71 & 59.7 & 48 & 40.3 & 119 & 81.0 & 28 & 19.0 \\
\hline
\end{tabular}

Table 2 - Final logistic regression model with self-care competence as an outcome variable. North West Sanitary District. Belo Horizonte, MG, Brazil, 2015 ( N=148)

\begin{tabular}{|c|c|c|c|}
\hline Variables & $\mathrm{OR}^{*}$ & $95 \% \mathrm{Cl}^{\dagger}$ & P-value \\
\hline Retirement & & $0.12-0.68$ & 0.005 \\
\hline No & 1.00 (ref.) & & \\
\hline Yes & 0.29 & & \\
\hline Skin pinching for application & & $1.68-10.05$ & 0.002 \\
\hline Properly/do not perform & 1.00 (ref.) & & \\
\hline Improperly & 4.11 & & \\
\hline Perform capillary glycemia & & $1.17-6.32$ & 0.020 \\
\hline No & 1.00 (ref.) & & \\
\hline Yes & 2.72 & & \\
\hline
\end{tabular}




\section{Discussion}

In this study, an adequate self-care competence in the administration of insulin was identified among participants. The results revelead the mental limitation as the indicator that most affected the self-care competence. Previous studies have shown that cognitive impairment increases the risk of nonadherence to diet, lack of glycemic monitoring, inadequate metabolic control, impaired quality of life ${ }^{(23)}$, severe hypoglycemia(24), and difficulty performing complex self-care tasks, such as inadequate self-administration of insulin and inadequate dietary maintenance in terms of time and content. In this context, older people with cognitive impairment should be subject of individualized actions performed by health professionals, which require the participation of caregivers and family members and special attention to the detection of possible occurrence of hypoglycemia(5).

An important finding of this study is the high percentage of participants with altered metabolic control, which may have been influenced by the inadequate self-care competence. A study carried out with diabetic patients undergoing insulin therapy for two years or more demonstrated a positive association between adequate glycemic control and confidence in the choice of insulin dosage, as well as a proper time interval between applications ${ }^{(15)}$. Inappropriate doses and applications of insulin may alter glycemic levels and cause a higher or lower rate of drug absorption.

Preprandial blood glucose readings in adults should not exceed $130 \mathrm{mg} / \mathrm{dL}$ and the desirable HbA1c level is up to $7 \%$. In older people, the tolerable HbA1c level is $8 \%$, due to their greater vulnerability to hypoglycemic episodes and high risk of falls ${ }^{(7)}$. International recommendations suggest that, for functionally dependent older people, the target for $\mathrm{HbA} 1 \mathrm{c}$ levels ranges from 7 to $8 \%$ and, specifically, for fragile older people or those with mental illness, these levels may reach up to $8.5 \%{ }^{(25)}$.

Motor and visual limitations are additional aggravating factors, which may compromise the insulin self-application technique, making it difficult to handle the application device accurately and therefore have an impact on the metabolic control(10). It should be noted that one in three participants had diabetic retinopathy, and vision impairment or loss of vision may affect the self-administration of insulin performed by older people, since it is necessary to visualize the syringe's graduation to ensure the right application dose and differentiate the types of insulin. It is important to note that the numbers indicating the graduation on the syringe are usually small, and sometimes with faint or blurred outlines, and the letters printed on the insulin vials indicating the insulin type and the expiration date are very small, which makes it difficult for older people to see.

In another respect, the high percentage of polypharmacy evidenced in this study is cause for concern, possibly due to the high burden of chronic diseases among long-lived individuals. A population-based study on Health, Well-Being and Aging (SABE), conducted in São Paulo, SP, Brazil, with people aged 60 years or over, found that individuals aged 75 years or over are 1.9 times more likely to have polypharmacy (OR: 1.9, 95\% CI: 1.3-2.7, p-value: 0.001 ), in relation to younger age groups; and diabetes was the predictor variable showing the greatest strength of association with outcome (OR: 4.1, 95\% CI: 2.2-7.5, $\mathrm{p}$-value $<0.001)^{(26)}$. The therapeutic complexity associated with multiple comorbidities can lead to an inappropriate use of medications by older people, making self-care more complex, especially in cases where cognitive alterations are present. In addition, polypharmacy increases the chances of drug interactions and side effects, which can lead to intoxications, potentiation of drug effects and increased risk of falls ${ }^{(5)}$.

It is worth mentioning that almost all older people with diabetes also had $\mathrm{SAH}$, which probably requires the concomitant use of antihypertensives. Previous studies ${ }^{(27-28)}$ have demonstrated the influence of antihypertensive agents on glycemic control, pointing out the thiazide diuretics and beta-blockers as the pharmacological classes associated with insulin resistance and poor glycemic control.

Regarding the frequency of errors and successes in self-administration of insulin, handwashing was not performed by the majority of participants, a result that did not coincide with that of two other similar studies. One of these studies, conducted by phone contact, found that only $3.9 \%$ of participants did not perform handwashing(29), and the other study, carried out through a semi-structured interview, found that $11.2 \%$ performed handwashing sometimes or never ${ }^{(30)}$. The recommendation is to wash hands with soap and water before preparing insulin ${ }^{(31)}$.

Regarding air aspiration in the syringe and injection into the insulin vial prior to aspiration of the content, most participants did not perform this procedure, a result similar to that found in other studies ${ }^{(29-30)}$. Air should be injected into the insulin vial in the amount corresponding to the dose to be drawn from the vial to prevent vacuum inside the vial(7).

Regarding the disposal of sharps, approximately half of the older people discarded sharps in a hard flask and only half of them performed the procedure properly. Similar results were found in a recent study conducted in the city of Fortaleza, CE, Brazil, which showed that $57.1 \%$ of the participants discarded in an inappropriate manner the waste generated by the administration of insulin in the ordinary household waste, even though they had been instructed on the appropriate manner to perform the disposal of this material(13). International studies ${ }^{(32-33)}$ also found high percentages of inappropriate waste disposal resulting from insulin therapy, and the possible reason for this finding was the unsatisfactory impact of continuing education on the safe disposal of sharps. As a 
consequence, there is an increased risk of contamination of the environment, transmission of pathogens and accidents with sharps, which demands the intensification of sanitary measures and greater commitment of health professionals in the guidance of the community ${ }^{(16)}$.

Considering the possible predictors of self-care competence, this study confirmed the multifactorial nature of the phenomenon in evidence, and self-care competence was associated with both the sociodemographic and clinical characteristics and the performance of selfadministration of insulin by older people.

A negative association was found between retirement and self-care competence, which may be due to the time devoted to self-care over a lifetime. Since all older people were over 70 years, the mandatory retirement age, it can be inferred that older people who paid their national insurance contributions (INSS), and possibly worked outside the home throughout their lives, dedicated less attention to take care of DM than older people who worked at home and had more free time to take care of their health, as well as to activities to encourage self-care behaviors in DM management, such as participation in operative groups.

Regarding the effect of CG monitoring on self-care competence, a positive association was identified, ie, older people who performed CG monitoring regularly also showed an adequate self-care competence. This association was already expected, since one of the selfcare activities of the insulin user is the CG monitoring, an important practice to monitor the individual and for the adequacy of the insulin dose required for the individualized treatment of DM.

A study conducted in the city of Botucatu, SP, Brazil, identified that only $9.7 \%$ of the users were competent to take actions based on the results of CG monitoring, at home. To make matters worse, health professionals underutilized the results of CG self-monitoring performed by users. The authors emphasize that CG self-monitoring at home allows the development of autonomy and decision-making skills in order to achieve an adequate glycemic control, and consequently, a reduction of the acute and chronic complications of the disease and the improvement of quality of life (34).

Considering the positive association found between the performance of skin pinching and the self-care competence, it is understood that older people who perform skin pinching for the administration of insulin also showed self-care competence. Properly performing the skin pinching during insulin administration ensures effective absorption of insulin into the subcutaneous tissue and avoids the risk of hypoglycemia in cases of accidental intramuscular administration, as well as the extravasation of medication, pain, local reaction and elevation of the skin and hyperglycemia in case of intradermal administration ${ }^{(35)}$.
One of the essential ways of making the person with DM aware of the importance of self-care is through the implementation of educational practices, and the participation of the nurse in these practices is fundamental. To educate aiming at promoting self-care competence depends on the professional's technical competence, as well as the patient's willingness and interest ${ }^{(36)}$. The objective of this educational process is to provide strategies that promote behavior change, contributing to the improvement of the quality of life of the person with $\mathrm{DM}^{(37)}$.

Regarding the limitations of this study, the lack of references on the self-application of insulin specifically by the older people is highlighted, which made it difficult to develop the statistical calculations for the estimation of sample size and the calculation of the sample power. Since this is a cross-sectional study, it was not possible to establish a cause and effect relationship between the variables.

Other limitations should be considered, such as difficulty in telephonic contact with the older people due to incorrect or missing telephone numbers, lack of financial resources and short deadlines that did not allow search for the addresses without a prior telephone contact.

\section{Conclusion}

Based on the results of this study, it was identified that handwashing, air aspiration in the syringe and injection in the insulin vial and disposal of sharps in a hard flask are the main errors in the self-application of insulin. Only the mental limitation showed a strong correlation with self-care competence. Retirement, performance of CG monitoring and skin pinching for insulin application were associated with the outcome variable.

In view of these results, it is considered essential the interdisciplinary care to the older person with DM through a special and individualized care, which must be provided to this population. In addition, identifying and analyzing errors and difficulties related to the selfcare competence in the administration of insulin in older people aged 70 or over with DM, enables professionals to contribute in their area of knowledge and stimulate a comprehensive care focused on older people.

\section{Acknowledgments}

To Thais Teixeira Lima, Dianna Silva de Oliveira, Ana Carolina Santana Ferreira and Marina Regis Moreira Ribeiro, for the data collection, and to Liliam Barbosa Silva, for the elaboration of the database.

\section{Referências}

1. Duncan BB, Schmidt MI, Cousin E, Moradi-Lakeh M, Passos VMA, França EB, et al. The burden of diabetes and hyperglycemia in Brazil-past and present: findings from the Global Burden of Disease Study 2015. Diabetol 
Metab Syndr. [Internet]. 2017 [cited June 25, 2017];9:18. Available from: https://www.ncbi.nlm.nih.gov/pmc/ articles/PMC5348777/pdf/13098_2017_Article_216.pdf 2. International Diabetes Federation. Diabetes atlas. 7th ed. United Kingdom: IDF; 2015. 142 p. [Internet]. [cited June 20, 2017]. Available from: http://www.diabetesatlas. org/resources/2015-atlas.html

3. Malta DC, Bernal RTI, Iser BPM, Szwarcwald CL, Duncan BB, Schmidt MI. Factors associated with selfreported diabetes according to the 2013 National Health Survey. Rev Saúde Pública. [Internet]. 2017 [cited June 29, 2017];51(Suppl 1):12s. Available from: http://www.scielo.br/pdf/rsp/v51s1/0034-8910rsp-S1518-87872017051000011.pdf

4. Lee EA, Gibbs NE, Martin J, Ziel F, Polzin JK, PalmerToy $D$. Improving care in older patients with diabetes: a focus on glycemic control. Perm J. [Internet]. 2016 Summer [cited June 22, 2017];20(3):51-6. Available from: https://www.ncbi.nlm.nih.gov/pmc/articles/PMC499 1915/pdf/permj20_3p0051.pdf

5. Kirkman MS, Briscoe VJ, Clark N, Florez H, Haas LB, Halter JB, et al. Diabetes in Older Adults. Diabetes Care. [Internet]. 2012 Dec [cited June 22, 2017];35(12):265064. Available from: https://www.ncbi.nlm.nih.gov/pmc/ articles/PMC3507610/pdf/2650.pdf

6. Selvin E, Parrinello CM, Daya N, Bergenstal RM. Trends in insulin use and diabetes control in the U.S.: 19881994 and 1999-2012. Diabetes Care. [Internet]. 2016 Mar [cited June 16, 2017];39(3):e33-5. Available from: https://www.ncbi.nlm.nih.gov/pmc/articles/PMC476 4038/pdf/dc152229.pdf

7. Sociedade Brasileira de Diabetes. Diretrizes da Sociedade Brasileira de Diabetes 2015-2016. 2016. 337 p. [Internet]. [cited June 20, 2017]. Available from: http:// www.diabetes.org.br/sbdonline/images/docs/DIRETRIZESSBD-2015-2016.pdf

8. Ministério da Saúde (BR). Secretaria de Atenção à Saúde. Departamento de Atenção Básica. Documento de diretrizes para o cuidado das pessoas com doenças crônicas nas Redes de Atenção à Saúde e nas linhas de cuidado prioritárias. 2012. [Internet]. [cited Nov 22, 2016]. Available from: dab.saude.gov.br/portaldab/ biblioteca.php?conteudo=publicacoes/Documento _doencas_crônicas

9. Orem DE. Nursing concepts of practice. Mac Grawn Hill; 1971.

10. Stacciarini TSG, Caetano TSG, Pace AE. Prescribed insulin dose versus prepared insulin dose. Acta Paul Enferm. [Internet]. 2011 [cited June 19, 2017];24(6):78993. Available from: http://www.scielo.br/pdf/ape/v24n6/ en_a10v24n6.pdf

11. Kim KS, Kim SK, Sung KM, Cho YW, Park SW. Management of type 2 diabetes mellitus in older adults. Diabetes Metab J. [Internet]. 2012 Oct [cited June 16, 2017];36(5):336-44. Available from: https://www.ncbi. nlm.nih.gov/pmc/articles/PMC3486979/pdf/dmj-36-336.pdf
12. Goto M, Goto A, Ikeda N, Noda H, Shibuya K, Noda M. Factors associated with untreated diabetes: analysis of data from 20,496 participants in the Japanese National Health and Nutrition Survey. PLoS One. [Internet]. 2015 Mar [cited June 16, 2017];10(3):e0118749. Available from: http:// journals.plos.org/plosone/article/file?id=10.1371/journal. pone. 0118749\&type=printable13. Cunha GH, Barbosa RVA, Fontenele MSM, Lima MAC, Franco KB, Fechine FV. Insulin therapy waste produced in the households of people with diabetes monitored in Primary Care. Rev Bras Enferm. [Internet]. 2017 May-June [cited June 16, 2017];70(3):618-25. Available from: http://www.scielo. br/pdf/reben/v70n3/0034-7167-reben-70-03-0618.pdf 14. Geller AI, Shehab N, Lovegrove MC, Kegler SR, Weidenbach KN, Ryan GJ, et al. National estimates of insulinrelated hypoglycemia and errors leading to emergency department visits and hospitalizations. JAMA Intern Med. [Internet]. 2014 May [cited June 16, 2017];174(5):67886. Available from: https://www.ncbi.nlm.nih.gov/pmc/ articles/PMC4631022/pdf/nihms731980.pdf

15. Trief PM, Cibula D, Rodriguez E, Akel B, Weinstock RS. Incorrect insulin administration: a problem that warrants attention. Clin Diabetes. [Internet]. 2016 Jan [cited June 16, 2017];34(1):25-33. Available from: https://www. ncbi.nlm.nih.gov/pmc/articles/PMC4714726/pdf/25.pdf 16. Mekuria AB, Gebresillassie BM, Erku DA, Haile KT, Birru EM. Knowledge and self-reported practice of insulin injection device disposal among diabetes patients in Gondar Town, Ethiopia: a cross-sectional study. J Diabetes Res. [Internet]. 2016 [cited June 16, 2017];2016:1897517. Available from: https://www.ncbi.nlm.nih.gov/pmc/ articles/PMC5055957/pdf/JDR2016-1897517.pdf

17. Santos AJD, Rossi VEC, Oliveira MLD. Diabetic patients'knowledge about the self-application of insulin and proper sharps disposal. Nursing. [Internet]. 2011 [cited June 16, 2017];13(155):20913. Available from: http://bases.bireme.br/cgi-bin/wxi slind.exe/iah/online/?IsisScript=iah/iah.xis\& $\mathrm{src}=\mathrm{google} \& \mathrm{~b}$ ase $=$ LILACS\&lang $=p \&$ nextActio $\mathrm{n}=$ Ink\&exprSearch $=597422$ \&indexSearch $=I D$

18. Bolfarine $\mathrm{H}$, Bussab WO. Elementos de amostragem. Blucher; 2005.

19. Nunes AMP. The development a tool which intends to adult diabetics readiness for self-care. [DissertaçãoMestrado em Ciências da Enfermagem]. Florianópolis: Universidade Federal de Santa Catarina; 1982 [cited June 16, 2017]. Available from: https://repositorio.ufsc. br/handle/123456789/74965

20. Dupont WD, Plummer WDJR. Power and sample size calculations. A review and computer program. Control Clin Trials. [Internet]. 1990 [cited June 16, 2017];11(2):11628. Available from: https://www.ncbi.nlm.nih.gov/ pubmed/2161310

21. Barker C. Power and sample size calculations in JMP. SAS Institute. 2011 [cited Nov 22, 2016]. Available from: http://www.jmp.com/ 
22. Ministério da Saúde (BR). Resolução no 466, de 12 de dezembro de 2012. Aprova diretrizes e normas regulamentadoras de pesquisas envolvendo seres humano. Diário Oficial da União. [Internet]. 2012 [cited Nov 22, 2016];12. Available from: http://conselho.saude.gov.br/ resolucoes/2012/Reso466.pdf

23. Cuevas $H$, Stuifbergen A. Perceived cognitive deficits are associated with diabetes self-management in a multiethnic sample. J Diabetes Metab Disord. [Internet]. 2017 Feb [cited June 16, 2017];16:7. Available from: https://www.ncbi.nlm.nih.gov/pmc/articles/PMC531 2423/pdf/40200_2017_Article_289.pdf

24. Punthakee Z, Miller ME, Launer LJ, Williamson JD, Lazar RM, Cukierman-Yaffee T, et al. Poor cognitive function and risk of severe hypoglycemia in type 2 diabetes: post hoc epidemiologic analysis of the ACCORD trial. Diabetes Care. [Internet]. 2012 Apr [cited June 16, 2017];35(4):78793. Available from: https://www.ncbi.nlm.nih.gov/pmc/ articles/PMC3308284/pdf/787.pdf

25. Internation Diabetes Federation. IDF global guideline for managing older people with type 2 diabetes 2013. 2013. 94 p. [Internet]. [cited Nov 22, 2016]. Available from: https://www.idf.org/component/attachments/ attachments. html?id=985\&task= download

26. Carvalho MFC, Romano-Lieber NS, Bergsten-Mendes G, Secoli SR, Ribeiro E, Lebrão ML, et al. Polifarmácia entre idosos do Município de São Paulo - Estudo SABE. Rev Bras Epidemiol. [Internet]. 2012 Dec [cited June 29, 2017];15(4):817-27. Available from: http://www. scielo.br/scielo.php?script=sci_arttext\&pid=S1415790X2012000400013\&lng=en

27. Padwal R, Laupacis A. Antihypertensive therapy and incidence of type 2 diabetes: a systematic review. Diabetes Care. [Internet]. 2004 Jan [cited June 29, 2017];27(1):247-55. Available from: http://care. diabetesjournals.org/content/27/1/247.full-text.pdf 28. Taylor EN, Hu FB, Curhan GC. Antihypertensive medications and the risk of incident type 2 diabetes. Diabetes Care. [Internet]. 2006 May [cited June 29, 2017];29(5):1065-70. Available from: http://care. diabetesjournals.org/content/29/5/1065.full-text.pdf 29. Becker TAC, Teixeira CRDS, Zanetti ML. Nursing intervention in insulin administration: telephone follow-up. Acta Paul Enferm. [Internet]. 2012 [cited Nov 22, 2016];25(especial):67-73. Available from: http://www.scielo.br/scielo.php?script=sci_arttext\& pid $=$ S0103-21002012000 800011 .
30. Stacciarini TS, Pace AE, Haas VJ. Factors associated with insulin self-administration by diabetes mellitus patients in the Family Health Strategy. Cad Saúde Pública. [Internet]. 2009 [cited Nov 22, 2016];24(6):1314-22. Available from: https://www.ncbi.nlm.nih.gov/pubmed/ 18545757

31. Ministério da Saúde (BR). Estratégias para o cuidado da pessoa com doença crônica: diabetes mellitus. 2013. 160 p. [Internet]. [cited Nov 22, 2016]. Available from: http://189.28.128.100/dab/docs/portaldab/publicacoes/ caderno_36.pdf

32. Ishtiaq O, Qadri AM, Mehar S, Gondal GM, Iqbal T, Ali $S$, et al. Disposal of syringes, needles, and lancets used by diabetic patients in Pakistan. J Infect Public Health. [Internet]. 2012 Apr [cited June 22, 2017];5(2):1828. Available from: http://www.jiph.org/article/S18760341(12)00026-3/pdf

33. Kalra S, Mithal A, Sahay R, John M, Unnikrishnan AG, Saboo $B$, et al. Indian injection technique study: population characteristics and injection practices. Diabetes Ther. [Internet]. 2017 Jun [cited June 22, 2017];8(3):63757. Available from: https://www.ncbi.nlm.nih.gov/pmc/ articles/PMC5446372/pdf/13300_2017_Article_243.pdf 34. Augusto MC, Nitsche MJT, Carvalhaes MABL, Zanetti ML, Parada CMGL. Evaluation of the capillary blood glucose self-monitoring program. Rev. Latino-Am. Enfermagem. [Internet]. 2014 Sept-Oct [cited June 22, 2017];22(5):801-9. Available from: http://www.scielo.br/ pdf/rlae/v22n5/0104-1169-rlae-22-05-00801.pdf

35. Oliveira AOT, Miguel MD, Zanin SMW, Montrucchio DP, Leite SAO. Atenção farmacêutica voltada ao diabetes mellitus. Rev Ciênc Farm. [Internet]. 2014 [cited June 29, 2017];25(1):59-64. Available from: www.cff.org.br/ userfiles/file/noticias/Artigo\%20diabetes\%201.pdf

36. Pereira FRL. Promovendo o autocuidado em diabetes na educação individual e em grupo. Ciênc Cuid Saúde. [Internet]. 2009 [cited Nov 22, 2016];8(4):594-9. Available from: http://ojs.uem.br/ojs/index.php/CiencCuidSaude/ article/viewFile/9686/5391

37. Diógenes MAR, Souza AKP, Cavalcante IP, Lopes LCO, Rebello MMCB. Insulin therapy: knowledge and practices used by patients with type 2 diabetes mellitus. Rev Enferm UERJ. [Internet]. 2012 Dec [cited June 22, 2017];20(especial 2):746-51. Available from: http:// www.e-publicacoes.uerj.br/index.php/enfermagemuerj/ article/view/5998/4302

Received: Mar. $3^{\text {rd }} 2017$ Accepted: July $12^{\text {th }} 2017$
Corresponding Author:

Mayara Sousa Vianna

Universidade Federal de Minas Gerais

Departamento de Atenção à Saúde do Trabalhador

Av. Pres. Antônio Carlos, 6627

Bairro: Pampulha

CEP: 31270-901, Belo Horizonte, MG, Brasil

E-mail: mayarasv@yahoo.com.br
Copyright $\odot 2017$ Revista Latino-Americana de Enfermagem This is an Open Access article distributed under the terms of the Creative Commons (CC BY).

This license lets others distribute, remix, tweak, and build upon your work, even commercially, as long as they credit you for the original creation. This is the most accommodating of licenses offered. Recommended for maximum dissemination and use of licensed materials. 